\title{
Modeling Deficit Irrigation in Alfalfa Production
}

\author{
By Gokmen Tayfur, ${ }^{1}$ Kenneth K. Tanji, ${ }^{2}$ Member, ASCE, Brett House,${ }^{3}$ Frank Robinson, ${ }^{4}$ \\ Larry Teuber, ${ }^{5}$ and Gordon Kruse, ${ }^{6}$ Member, ASCE
}

\begin{abstract}
A conceptual agronomic model EPIC was extended to consider the effects of salinity in alfalfa production under optimal and water stress irrigation conditions. The extended model was calibrated and validated with observed lysimeter data. The model parameters that affected alfalfa yield and soil salinity the most were wilting point, field capacity, hydraulic conductivity, nitrate concentration, biomass energy ratio, seeding rate, average soil salinity $E C_{e}$ at which crop yield is reduced by $50 \%\left(E C_{50}\right)$, and initial soil gypsum concentration. The calibrated and validated model was then applied to an alfalfa deficit irrigation study. The four irrigation treatments included optimum check, minimum stress, short stress, and long stress, each of which produced differential alfalfa yields. The purpose of summer deficit irrigation was to ascertain how much agricultural water at what cost could be made available for urban water uses during water shortfalls. The results of model simulation were found to be satisfactory under all irrigation treatments though the model slightly overestimated the yields and underestimated the soil $E C_{e}$ at the end of short and long stress treatments. An economic component is included to determine the appropriate compensation for farmers undergoing a range of deficit irrigations.
\end{abstract}

\section{INTRODUCTION}

Throughout its history, irrigated agriculture has been plagued by soil salinization and waterlogging. Currently, about $20,000,000$ ha of the total $230,000,000$ ha of irrigated land in the world are salt-affected (Kovda 1983). In California alone, nearly $1,800,000$ ha of the total $3,700,000$ ha of irrigated cropland are affected by salt problems. The impacts of salinity are felt on the farm as well as off the farm (Tanji 1990). Best management practices (BMPs) are being promulgated for nonpoint sources (NPSs) of agricultural sources of pollution. BMPs are legally defined by the Federal Clean Water Act of 1977 as methods that minimize NPS pollution, while remaining economically viable for the producer. However, the effectiveness and costs of BMPs are not well known (Tanji et al. 1994). BMPs for salinity control, for instance, can be determined from field experiments by comparing different irrigation and agronomic practices and assessing salt leaching and economic returns. However, a BMP for one set of crop, soil, and climatic conditions may not be a BMP for another set of crop, soil, and climatic conditions. Considering California alone, with hundreds of crops on numerous soil types and under different climatic conditions, such an effort would be time-consuming, costly, and inefficient. Instead, the agronomic system can be modeled as a function of crops, soils, climate, fertilization, and drainage in order to assess the effectiveness of BMPs.

A conceptual agronomic model known as EPIC (Erosion/ Productivity Impact Calculator) was utilized in the present study (Sharply and Williams 1990). EPIC was chosen because it closely satisfied the primary criteria-meeting the level of

\footnotetext{
'Assist. Prof., Dept. of Civ. Engrg., Izmir Inst. of Technol., Basmane, Izmir 35230, Turkey.

'Prof., Dept of Land, Air and Water Res., Univ. of California, Davis, CA 95616.

${ }^{3}$ Grad. Res. Asst., Dept. of Agric. Economics, Univ. of California, Davis, CA.

'Water Sci. (Retired), Desert Research and Extension Center, El Centro, CA 92243.

'Prof., Dept. of Agronomy, Univ. of California, Davis, CA.

Agric. Engr. (Retired), Agric. Res. Service, USDA, Fort Collins, CO 80523 .

Note. Discussion open until May 1, 1996. To extend the closing date one month, a written request must be filed with the ASCE Manager of Journals. The manuscript for this paper was submitted for review and possible publication on January 12, 1995. This paper is part of the Journal of Irrigation and Drainage Engineering, Vol. 121, No. 6, November/ December, 1995. CASCE, ISSN 0733-9437/95/0006-0442-0451/\$2.00+ $\$ .25$ per page. Paper No. 9942.
}

sophistication required to assess BMPs, while reducing the scope of required input data to readily attainable information - for both research and management purposes (Warden et al. 1992). EPIC was successfully applied to evaluate nitrate leaching losses from irrigated, fertilized lettuce fields, and the costs of BMPs (Warden et al. 1992; Jackson et al. 1994). Although EPIC has most of the components of an agronomic system, it did not include a salinity component. So we extended EPIC to model salinity in irrigated lands cropped to alfalfa. The soil salinity modeling involved two parts. The first part was to model salt movement due to water flow (runoff, percolation, and lateral subsurface flows) through soil layers. The second part was to model the dissolution and precipitation of gypsum, which, respectively, acts as source and sink for salts in the soil. Gypsum is one of the major contributors of dissolved mineral salts in waters from gypsiferous irrigated lands. In agricultural lands containing gypsum, salinity in the soil solution and drainage waters changes beyond the expected limits of assuming conservative behavior of salts (Tanji 1990). When solid-phase gypsum comes into contact with water it may dissolve and contribute calcium and sulfate ions into the soil solution, increasing soil salinity. But when the soil water is evapoconcentrated from root water extraction and surface evaporation, the calcium and sulfate ions may evapoconcentrate to such a degree that gypsum precipitates, reducing soil salinity.

The EPIC model extended to consider salinity was calibrated and validated with observed field data obtained at the Fruita Research Center of Colorado (Champion et al. 1991; Kruse et al. 1993). Then, the model was used to simulate salinity and biomass in alfalfa production in the Imperial Valley of California under various water stress management practices during the summer (Robinson et al. 1992, 1994). The main crop in the Imperial Valley is alfalfa, which is a high water user. Water shortage in the urban areas of Southern California, especially during the summer months, is well known. Reducing irrigation water applied to alfalfa in this valley will result in significant water savings that can be reallocated for urban use. For example, the elimination of a single irrigation $(12.2 \mathrm{~cm}$ ) will save enough water (about $927,000 \mathrm{ha} \cdot \mathrm{cm}$ ) to supply the water needs of about 510,000 persons for a whole year (Robinson et al. 1992). One of the main objectives of the study by Robinson et al. (1994) was to determine the amount of reduction in irrigation water that can be tolerated by alfalfa, the consequent increase in soil salinity, and yield reduction. In this respect, they performed four different irrigation treatments - optimum check, minimum stress, short 
stress, and long stress. Stress treatments involved elimination of some portion of the irrigation water during the summer months. The economic component of the present paper follows the procedures used by Robinson et al. (1992). Also, the opportunity cost of the different deficit irrigation programs is estimated for various levels of salinity in the irrigation water. The opportunity cost displays the value of water that would be paid by urban users to farmers who undergo deficit irrigation with potential yield reduction.

\section{MATHEMATICAL FORMULATION}

\section{Downward Salt Movement}

Modeling downward salt movement through soil layers involves two parts. The first part is to model salt movement in the surface layer $(10 \mathrm{~mm}$ thick) of an agricultural land. The total water flow $(W)$ leaving the surface layer consists of surface runoff $(R)$, lateral subsurface flow $(L)$, and vertical percolation $(I)$. The second part is to model salt movement in other soil layers. In these other layers, the total water flow consists of lateral subsurface flow and vertical percolation.

The formulation of downward salt movement is analogous to that of nitrate leaching, developed by Sharply and Williams (1990)

$$
S=S_{i}\left[1-\exp \left(\frac{-W}{P_{o}-P_{l}}\right)\right]
$$

where $S=$ salt mass associated with the total water flow; $S$ $=$ initial salt mass in the soil layer; $P_{o}=$ soil porosity; and $P_{l}=$ wilting point water content

The final salt mass in any soil layer is expressed as

$$
S_{f}=S_{i}-S
$$

where $S_{f}=$ final salt mass contained in the soil layer.

The average concentration of salt is expressed as

$$
C_{S}=S / W
$$

where $C_{S}$ represents the average salt concentration associated with the total water flow.

Salt masses contained in runoff, lateral flow, and percolation are estimated as the products of the corresponding water flows and the salt concentration from (3).

\section{Upward Salt Movement}

Upward salt movement formulation is analogous to that of upward nitrate movement, developed by Sharply and Williams (1990). When water is evaporated from the soil surface, salt is moved upwards into the top soil layer by mass flow. The equation for estimating this salt transport is expressed as

$$
S_{e v i}=\sum_{l=2}^{n}\left(E_{v i} \cdot C_{s l}\right)
$$

where $S_{e r}$, salt mass moved from lower layers to the top layer by soil water evaporation; and $E_{v}$, represents the amount of soil water evaporation. Subscript $l$ refers to soil layers and $n$ represents the number of layers contributing to soil water evaporation.

\section{Gypsum Dissolution}

Modeling gypsum dissolution involves two parts. The first part is to model gypsum dissolution at the $100 \mathrm{~mm}$ thick soil surface layer. The next part is to model gypsum dissolution in other soil layers.
The time-dependent gypsum dissolution is defined as (Kemper et al. 1975)

$$
d C_{g} / d t=K\left(C_{g s}-C_{g}\right)
$$

where $C_{g}=$ the solution concentration at any time; $C_{g s}=$ solution concentration at gypsum saturation, which is taken as $4 \%$ ( $\mathrm{g}$ of gypsum $/ \mathrm{g}$ of soil) or $2.63 \mathrm{~g} / \mathrm{L}$ in the soil solution (Karajeh 1991); and $K=$ dissolution coefficient.

Integrating (5) between $t=0$ when water enters the soil element and $t=t_{c}$ when water leaves the element will yield the following equation:

$$
-\ln \left(1-\frac{C_{g}}{C_{g s}}\right)=K t_{c}
$$

Keren and O'Connor (1982) conducted a gypsum dissolution study using soil samples amended with $2 \%$ and $4 \%$ gypsum under different water flow velocities. From this study, they concluded that the right-hand side of (6) can be expressed as

$$
K t_{c}=\alpha t_{c}^{0.5}+\beta
$$

where $\alpha$ and $\beta=$ coefficients of the linear function. Kemper et al. (1975) expressed the time $t_{c}$ as

$$
t_{c}=T / V
$$

where $T=$ thickness of the soil element; and $V=$ actual flow velocity. Actual flow velocity is equal to Darcy velocity divided by soil porosity $\left(v / P_{o}\right)$ (Keren and O'Connor 1982). Darcy velocity $v$ is equal to flow flux $W$ and soil porosity $P_{o}$ can be assumed to be equal to the saturated moisture content of the soil element $\theta_{s}$ (Karajeh and Tanji 1994). Hence, the gypsum dissolution coefficient can be expressed as

$$
K=\alpha\left(\frac{W}{T \theta_{s}}\right)^{0.5}+\beta \frac{W}{T \theta_{s}}
$$

From the experimental studies of Keren and O'Connor (1982), $\beta=0$ and $\alpha$ is taken as: $\alpha=1.2 \mathrm{~h}^{-0.5}$ for $0.0 \% \leq$ gypsum $\leq 2.0 \%$; and $\alpha=2.55 \mathrm{~h}^{-0.5}$ for $2.0 \%$ gypsum $\leq 4.0 \%$. Gypsum dissolution can be computed for anytime as (Karajeh and Tanji 1994)

$$
C_{g}(t)=K(t) \cdot \theta(t) \cdot C_{g}(t-1)
$$

where $(t)$ and $(t-1)$ represent the current and previous time steps, respectively; $\theta=$ soil moisture content; and $K=$ computed by (9).

The mass of dissolved gypsum in each flow can be calculated as the product of gypsum concentration obtained from (10) and the corresponding flow fluxes.

\section{Gypsum Precipitation}

Gypsum precipitation due to the soil water evaporation can be expressed as

$$
G_{p}=\sum_{i=2}^{n}\left(E_{r \prime} \cdot C_{R^{\prime}}\right)
$$

where $G_{p}=$ mass of the calcium and the sulfate ions that were evapoconcentrated and precipitated back to gypsum as a result of the soil water evaporation $E_{z}$ and occurring from lower layers to the top layer.

\section{Total Salt Mass Balance}

The total salt mass balance in any soil layer $(l)$ can be expressed as

$$
T_{s l}=S_{i l}-\left(S_{l}+G_{d l}\right)+\left(S_{e r l}+G_{p l}\right)
$$


where $T_{s t}$ and $S_{i l}=$ final total salt mass and the initial salt mass in the soil layer $l$, respectively; $S_{l}=$ salt mass lost from soil layer $l$ due to the total water flow leaving that soil layer; $G_{d l}=$ mass of dissolved components (the calcium and sulfate ions) of gypsum lost from the soil layer $l$ due to the total water flow leaving that soil layer; $S_{r^{\prime}, l}=$ salt mass moved to the soil layer $l$ from the contributing lower layers due to the soil water evaporation; and $G_{p l}=$ mass of precipitated components (calcium and sulfate ions) of gypsum moved to the soil layer $l$ due to the soil water evaporation.

The relation between final total salt mass $T_{s l}(\mathrm{t} / \mathrm{ha})$ and soil saturation extract $E C_{c}(\mathrm{dS} / \mathrm{m})$ in soil layer $l$ can be expressed as

$T_{s}(\mathrm{t} / \mathrm{ha})=E C_{e} \cdot 640\left(\mathrm{~g} / \mathrm{m}^{3}\right) \cdot \theta \cdot T(\mathrm{~m})$

$\cdot 10,000\left(\mathrm{~m}^{2} / \mathrm{ha}\right) / 1,000,000(\mathrm{~g} / \mathrm{t})$

where $T=$ the thickness of soil layer $l$.

\section{MODEL CALIBRATION AND VALIDATION}

\section{Model Calibration}

The salinity-extended EPIC model was calibrated with the 1986 alfalfa data obtained at Fruita Research Center in Grand Valley, Colo. The entire valley is underlain by the Mancos shale, a saline geological formation deposited under marine conditions. The shale is laden with gypsum crystals and the soils contain soluble salts. Deep percolation and seeping waters dissolve gypsum and displace soluble salts into the shallow ground and into the Colorado River (Champion et al. 1991). The soil at the Fruita Research Center is Youngston loam. The surface layer of a typical pedon is loam or sand clay loam, about $74 \mathrm{~cm}$ thick. The underlying material, to a depth of $150 \mathrm{~cm}$, is stratified loamy fine sand, silt loam, silty clay loam and very fine sandy loam. The Fruita Research Center
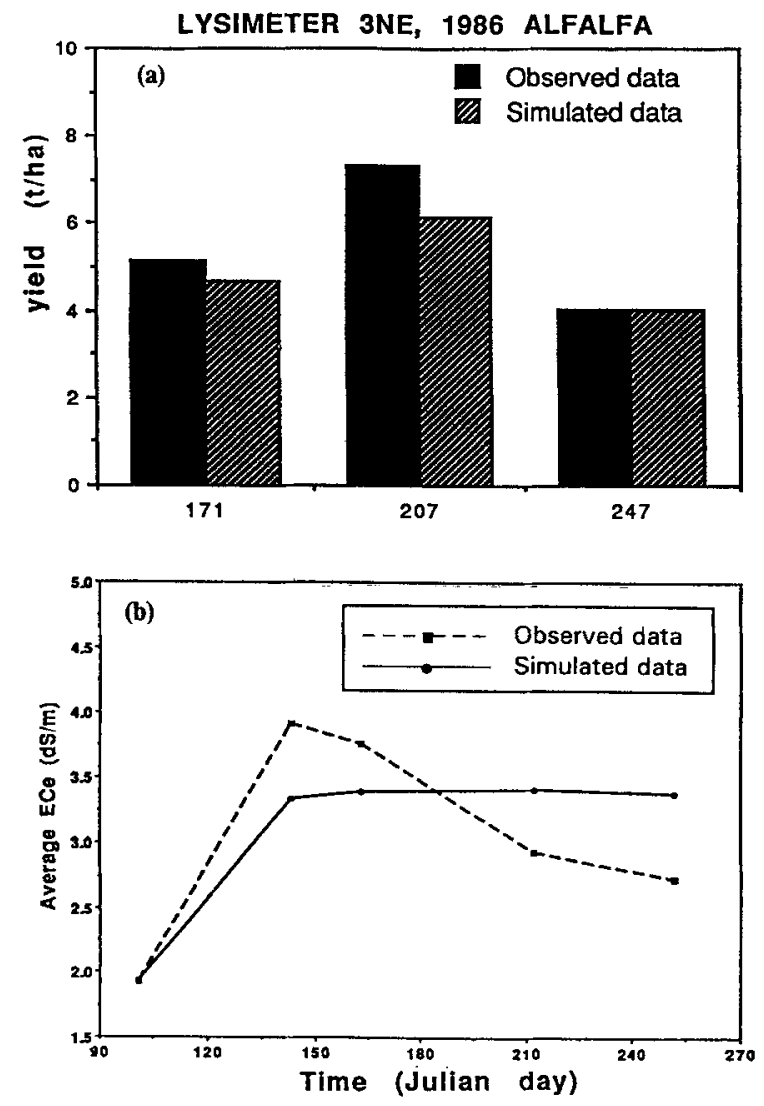

FIG. 1. Calibration Run-Comparison of Observed and Simulated: (a) Alfalfa Yield from Each Harvest; (b) Average Soil $E C_{e}$


FIG. 2. Calibration Run-Simulation of $E C_{e}$ Profile by Soil Depth at Various Times in Alfalfa Growing Season: (a) at Beginning (May 23); (b) at Middle (June 12); (c) at End (September 9)

Project was designed to have six benches, each $61 \times 61 \mathrm{~m}$. Each bench has two small basins, north and south. Pairs of hydraulic weighing lysimeters were placed in six of the small basins. Each lysimeter is $1.52 \times 1.22 \times 1.22 \mathrm{~m}$ deep. The details of lysimeters and their setup can be obtained from Kincaid et al. (1979) and details of the experimental site from Champion et al. (1991).

Weather, soil, irrigation, and harvesting data were obtained at the Fruita Research Center. The weather data consisted of daily maximum and minimum temperatures, solar radiation, wind speed, and precipitation. The soil data consisted of soil moisture and saturated soil extract $E C_{e}$. Dates and depths of irrigation applied to the north plot, south plot, and to the lysimeters were recorded, as were dates and amounts of harvesting from the north plot, south plot, and from the lysimeters. 
TABLE 1. Calibrated Values of Soil and Crop Parameters

\begin{tabular}{l|c|c|c}
\hline \multirow{2}{*}{$\begin{array}{c}\text { Parameter } \\
(1)\end{array}$} & \multicolumn{3}{c}{ Soil Layer Depth $(\mathrm{m})$} \\
\cline { 2 - 4 } & $\begin{array}{c}0-0.30 \\
(2)\end{array}$ & $\begin{array}{c}0.30-0.60 \\
(3)\end{array}$ & $\begin{array}{c}0.60-0.90 \\
(4)\end{array}$ \\
\hline \multicolumn{3}{c}{$($ a) Soil Parameters } \\
\hline Wilting point $(\mathrm{m} / \mathrm{m})$ & 0.116 & 0.120 & 0.059 \\
Field capacity $(\mathrm{m} / \mathrm{m})$ & 0.398 & 0.418 & 0.359 \\
Saturated conductivity $(\mathrm{mm} / \mathrm{h})$ & 2.500 & 5.500 & 8.200 \\
Nitrate concentrate $\left(\mathrm{g} / \mathrm{m}^{3}\right)$ & 16.00 & 11.00 & 9.000 \\
Labile P concentrate $\left(\mathrm{g} / \mathrm{m}^{3}\right)$ & 32.00 & 16.00 & 13.00 \\
Initial gypsum concentrate $(\mathrm{g} / \mathrm{L})$ & 0.0011 & 0.0046 & 0.0088 \\
\hline \multicolumn{4}{c}{$(\mathrm{b})$ Crop Parameters } \\
\hline Biomass-energy ratio & 50.00 & 50.00 & 50.00 \\
Seeding rate $(\mathrm{kg} / \mathrm{ha})$ & 50.00 & 50.00 & 50.00 \\
EC $_{50}(\mathrm{dS} / \mathrm{m})$ & 8.850 & 8.850 & 8.850 \\
\hline \hline
\end{tabular}
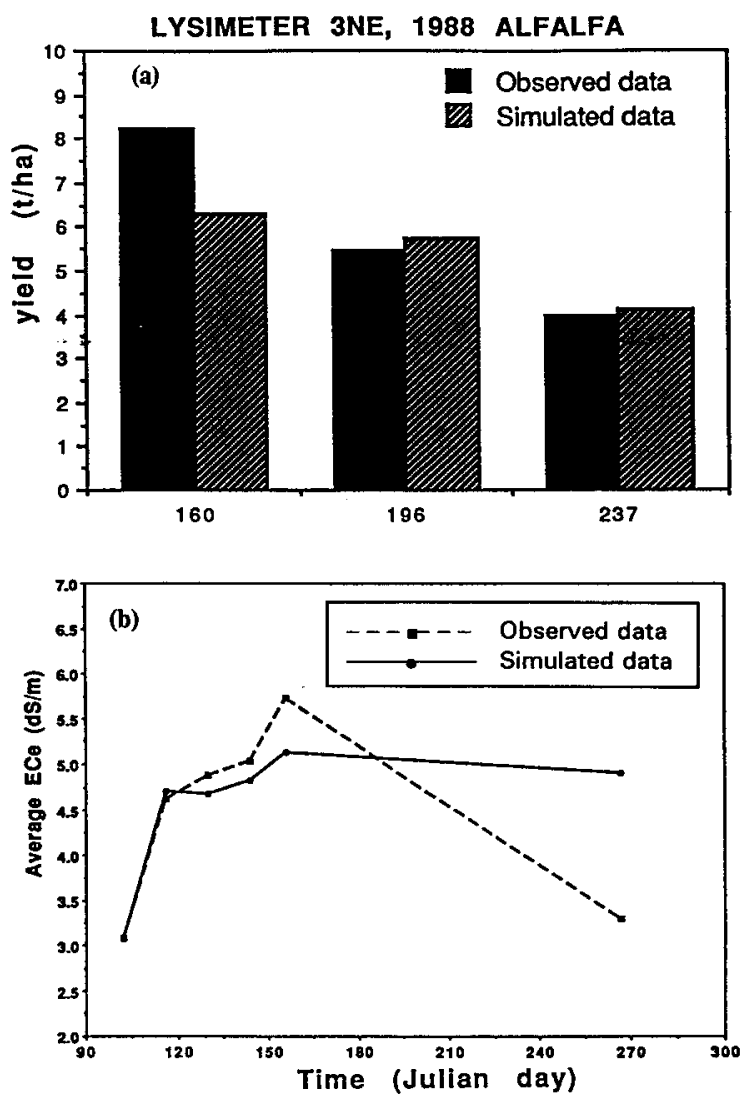

FIG. 3. Validation Run-Comparison of Observed and Simulated: (a) Alfalfa Yield from Each Harvest; (b) Average Soil $E C_{\text {o }}$

TABLE 2. Irrigation Treatments

\begin{tabular}{l|c|c|c|c}
\hline \multirow{2}{*}{\begin{tabular}{l} 
Irrigation treatment \\
\cline { 2 - 5 }$(1)$
\end{tabular}} & \multicolumn{4}{|c}{ Number of Irrigations } \\
\cline { 2 - 5 } & July & $\begin{array}{c}\text { August } \\
(2)\end{array}$ & $\begin{array}{c}\text { September } \\
(4)\end{array}$ & $\begin{array}{c}\text { October } \\
\text { (5) }\end{array}$ \\
\hline Optimum check & 3 & 2 & 2 & 2 \\
Minimum stress & 3 & 1 & 1 & 2 \\
Short stress & 3 & 0 & 0 & 2 \\
Long stress & 0 & 0 & 0 & 2 \\
\hline \hline
\end{tabular}

Data obtained from one of the lysimeters (3NE lysimeter) were used to calibrate the model. Alfalfa was planted in September 1985 and harvested three times in 1986-June 6, July 17, and August 25-yielding a total of $16.5 \mathrm{t} / \mathrm{ha}$ (G. Kruse, personal communication, 1993). The ground-water table was kept constant at $1.05 \mathrm{~m}$ below the soil surface during the alfalfa growing season (Kruse et al. 1993). The lysimeters
TABLE 3. Comparison of Observed and Simulated Total Alfalfa Yield

\begin{tabular}{l|c|c|c|c}
\hline \hline $\begin{array}{c}\text { Treatment } \\
(1)\end{array}$ & $\begin{array}{c}\text { Observed } \\
(\mathrm{t} / \mathrm{ha}) \\
(2)\end{array}$ & $\begin{array}{c}\text { Simulated } \\
(\mathrm{t} / \mathrm{ha}) \\
(3)\end{array}$ & $\begin{array}{c}\text { Difference } \\
(\mathrm{t} / \mathrm{ha}) \\
(4)\end{array}$ & $\begin{array}{c}\text { Difference } \\
\text { (percent) } \\
(5)\end{array}$ \\
\hline Optimum check & 12.51 & 11.50 & 1.01 & 8.1 \\
Minimum stress & 11.64 & 10.50 & 1.14 & 9.8 \\
Short stress & 8.95 & 9.50 & 0.55 & 6.2 \\
Long stress & 6.66 & 6.30 & 0.36 & 5.4 \\
\hline \hline
\end{tabular}
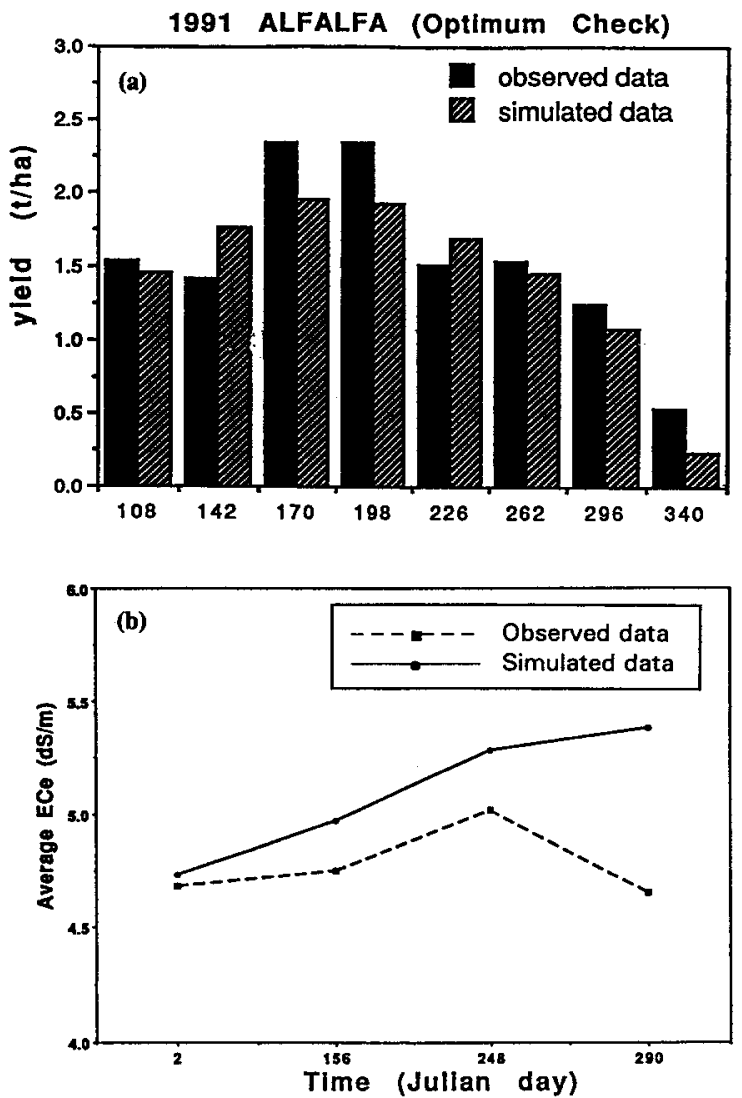

FIG. 4. Comparison for Optimum Check Irrigation Treatment of Observed and Simulated: (a) Alfalfa Yield from Each Harvest; b) Average Soil EC.

were surface irrigated with water supplied from Colorado River, which had an average $E C_{w}$ of $0.65 \mathrm{dS} / \mathrm{m}$ during the summer. Alfalfa in lysimeter $3 \mathrm{NE}$ received about $796 \mathrm{~mm}$ irrigation water from April 15, 1986 to September 23, 1986. Crop growth parameters of alfalfa in EPIC were synthesized from the literature.

The 1986 total alfalfa yield (t/ha), yield from each harvest (t/ha), average soil saturation extract $E C_{e}(\mathrm{dS} / \mathrm{m})$ and soil saturation extract $E C_{e}(\mathrm{dS} / \mathrm{m})$ profile along the soil depth were the primary variables in the calibration procedure. The total alfalfa yield obtained from the calibration run was equal to $14.7 \mathrm{t} / \mathrm{ha}$, which is $1.8 \mathrm{t} / \mathrm{ha}$ less than the observed total yield of $16.5 \mathrm{t} / \mathrm{ha}$. Figs. 1( $\mathrm{a}$ and $\mathrm{b}$ ) respectively show model calibration of the observed alfalfa yield ( $t / h a)$ obtained from each of the three cuttings and the average soil saturation extract $E C_{e}(\mathrm{dS} / \mathrm{m})$. Figs. 2(a, b, c) show the model calibration of measured $E C_{e}$ in the $0.3,0.6$, and $0.9 \mathrm{~m}$ soil depths at the beginning, middle and end of the alfalfa growing season. The model parameters having the most sensitivity on the calibrated yield and soil salinity were the wilting point, field capacity, saturated hydraulic conductivity, nitrate concentration, labile $\mathrm{P}$ concentration, biomass energy ratio, seeding rate, $E C_{50}$ (salinity at which crop yield is reduced by $50 \%$ ), 

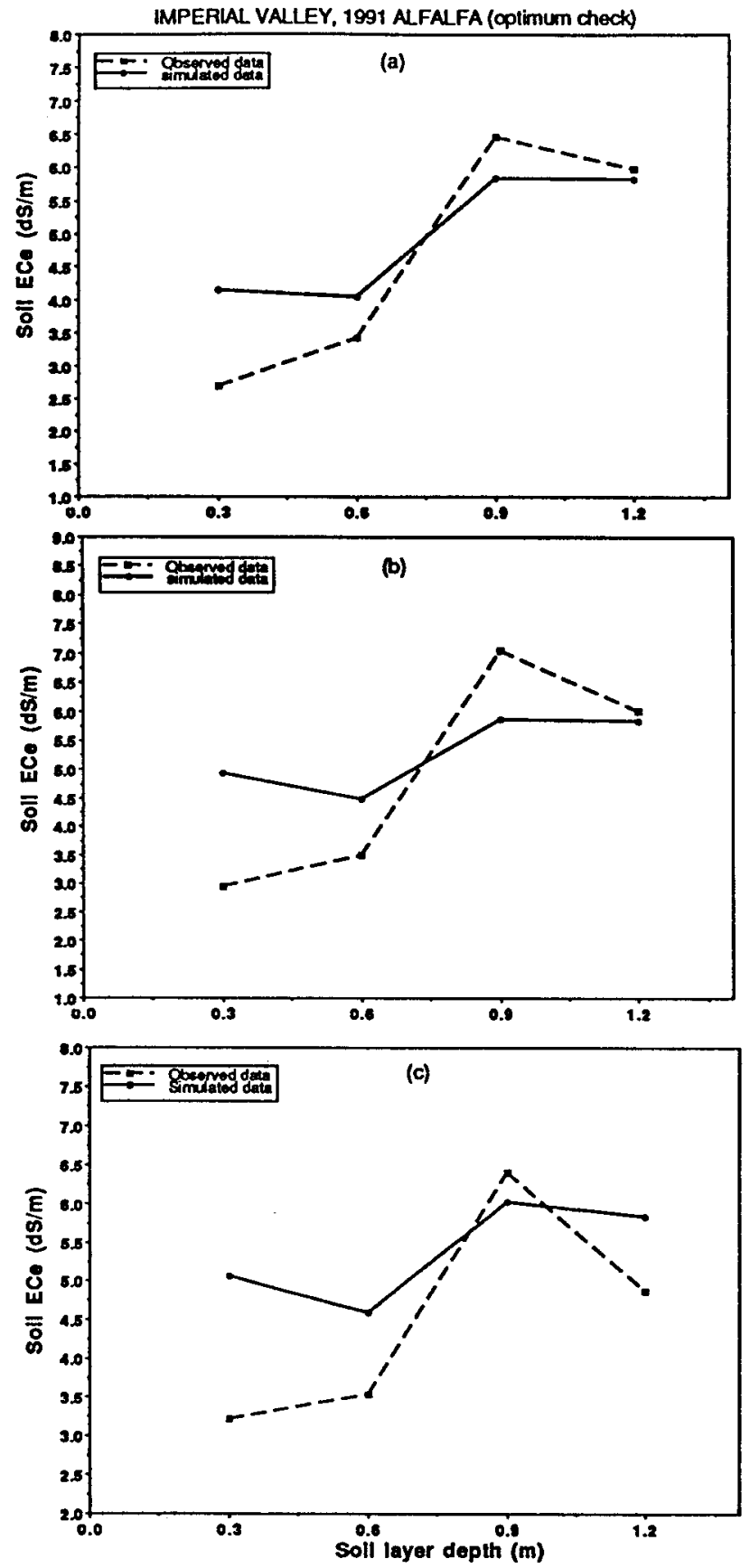

FIG. 5. Simulation for Optimum Check Treatment of Soil EC $\mathrm{e}_{\mathrm{e}}$ by Depth: (a) on June 4; (b) on September 4; (c) on October 16

and initial gypsum concentration in the soil profile. Since much of the data were not available on these parameters, their values had to be iteratively estimated through the calibration procedure. Table 1 gives the calibrated model parameters that resulted in the best fit for total yield, yield from each harvest [Fig. 1(a)], average soil $E C_{e}$ [Fig. 1(b)], and soil $E C_{e}$ at three profile depths at the beginning, middle, and end of alfalfa growing season [Figs. 2(a,b,c).

\section{Model Validation}

The EPIC model calibrated with the 1986 alfalfa lysimeter data was then validated with observed data from the 1988 alfalfa experiment carried out at the Fruita Research Center. Lysimeter $3 \mathrm{NE}$ was again chosen for the model validation. Calibrated values of the model parameters (Table 1) were used in the validation procedure. Alfalfa was harvested three times in 1988-June 8, July 14, and August 24-yielding a
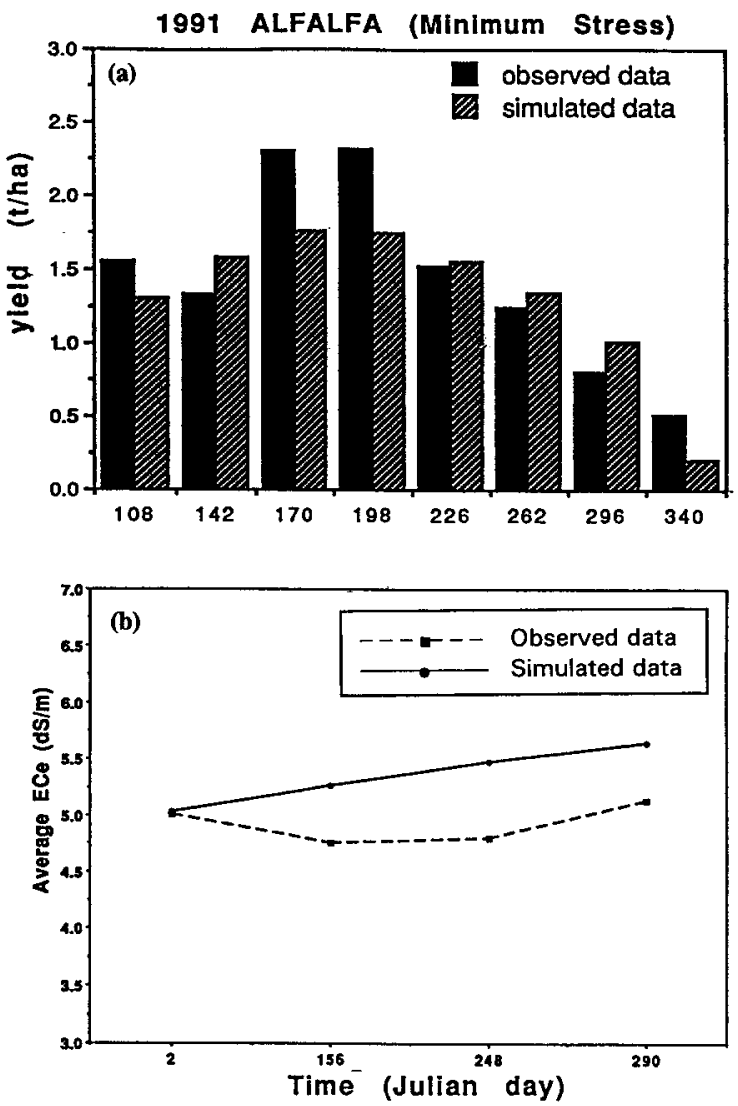

FIG. 6. Comparison for Minimum Stress Treatment of Observed and Simulated: (a) Alfalfa Yield from Each Harvest; (b) Average Soil $E C_{e}$

total of $17.7 \mathrm{t} /$ ha (Kruse et al. 1993). During the alfalfa growing season, the ground-water table was kept constant at 1.05 $\mathrm{m}$ (Kruse et al. 1993). Alfalfa in lysimeter $3 \mathrm{NE}$ received about $841 \mathrm{~mm}$ irrigation water from April 20, 1988 to September 16,1988 . The Colorado river irrigation water had an average $E C_{w}$ of $0.65 \mathrm{dS} / \mathrm{m}$.

For validation, the model estimated a total of $16.0 \mathrm{t} / \mathrm{ha}$ alfalfa yield in close agreement with the observed total yield of 17.7 t/ha. Fig. 3(a) shows a comparison of observed and simulated yield obtained from each of the three harvests. Fig. 3 (b) shows that the average soil $E C_{e}$ in the $0.9 \mathrm{~m}$ soil profile was simulated reasonbly well except for the last date.

\section{MODEL APPLICATION}

The EPIC model extended for salinity that had been calibrated and validated with lysimeter alfalfa data from Colorado was then applied to a 1992 study (Robinson et al. 1992) conducted in the Imperial Valley of California at the University of California's Desert Research and Extension Center. A major objective of the Imperial Valley field trials on alfalfa was to determine what effects a range of water stress during the summer would have on yield and opportunity costs.

Table 2 presents the treatments consisting of four levels of irrigations. The optimum check treatment received a total of $1,269 \mathrm{~mm}$ irrigation. The minimum stress treatment missed one irrigation in August and September as compared to the check and received a total of $1,203 \mathrm{~mm}$ irrigation. The short stress treatment did not receive any irrigation in August and September, missing four irrigations as compared to the check, and received a total of $991 \mathrm{~mm}$ irrigation. And the long stress treatment did not receive any irrigation in July, August, and September, missing seven irrigations as compared to the check, and received a total of $821 \mathrm{~mm}$ irrigation. The irrigation water 

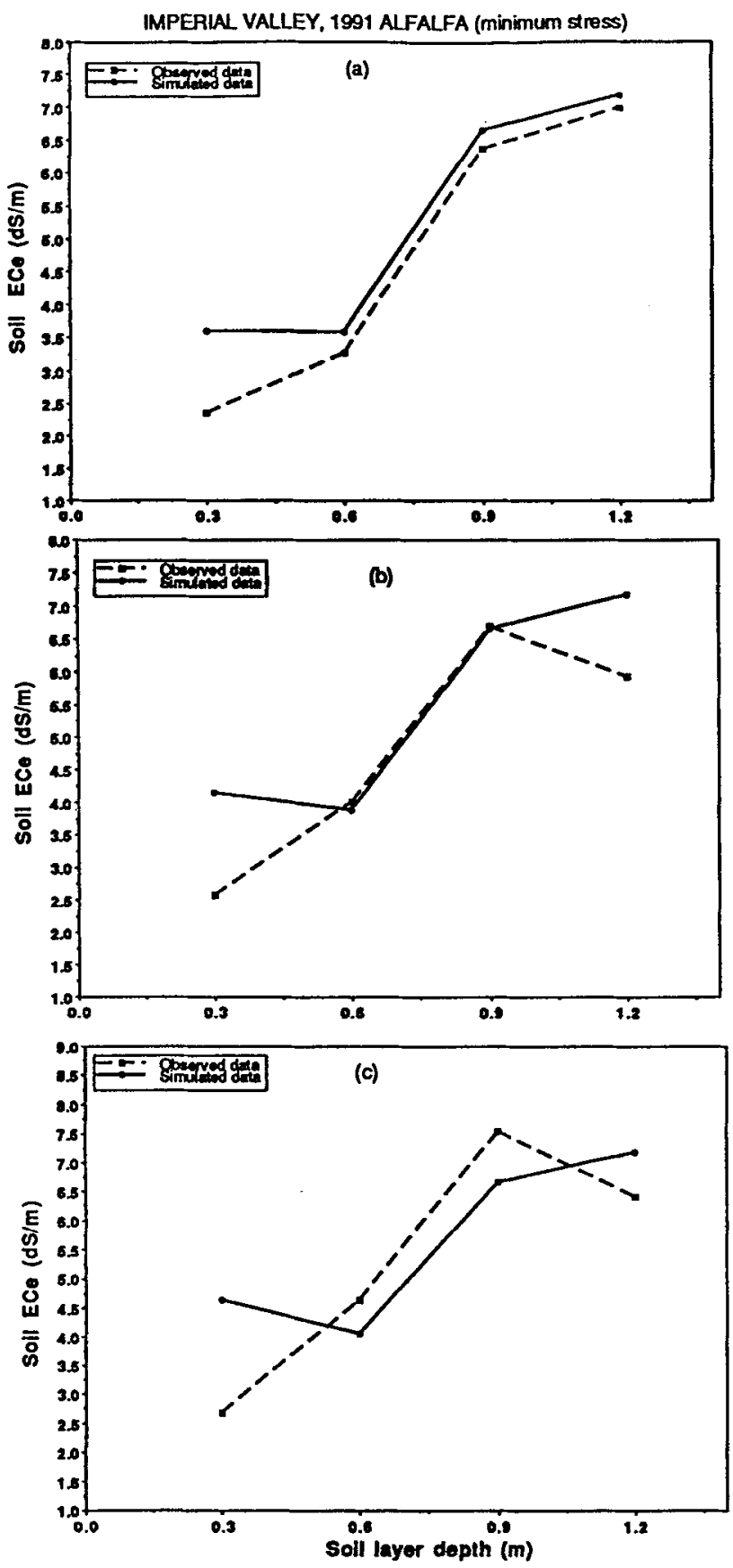

FIG. 7. Simulation for Minimum Stress Treatment of Soil EC by Depth: (a) on June 4; (b) on September 4; (c) on October 16

diverted from Colorado River into the All American Canal for the Imperial Irrigation District had an average $E C_{w}$ of $1.25 \mathrm{dS} / \mathrm{m}(850 \mathrm{mg} / \mathrm{L})$ (Khalid Bali, personal communication, 1993 ) about twice the $E C_{w}$ at the Fruita Research Center in Colorado. The soil in the Imperial Valley field study site is a Holtville clay extending $60 \mathrm{~cm}$ to $90 \mathrm{~cm}$ in depth overlying a sandy clay. The water table in this valley fluctuates around $1.7 \mathrm{~m}$ depth beneath the soil surface (Robinson et al. 1992).

Alfalfa was planted on October 23, 1990, the first harvest was on April 17, 1991 and seven additional harvests followed for the optimum check and minimum stress treatments. The short stress treatment had six harvests and the long stress treatment had five harvests in 1991 . Since data were not available on initial soil profile $E C_{e}$ on October 23, 1990, the observed soil $E C_{e}$ values on January 2, 1991 were assumed to be the initial soil $E C_{e}$ profile. Since the soil at this experimental site does not contain significant amounts of gypsum
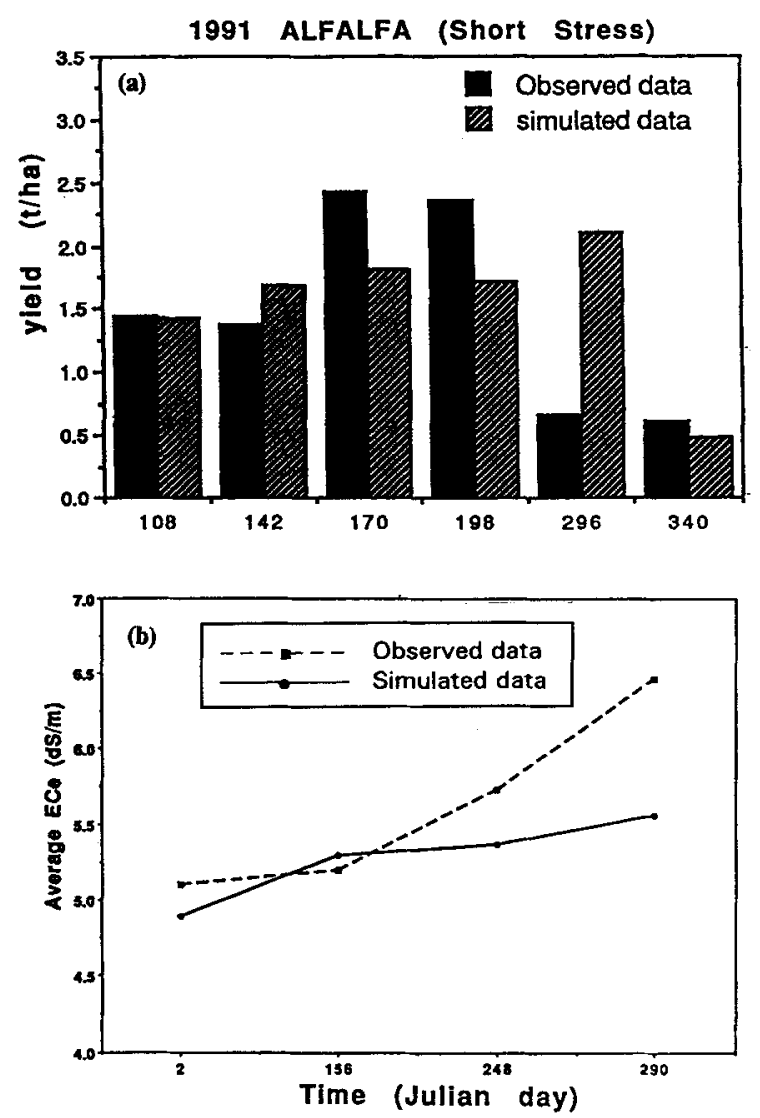

FIG. 8. Comparison for Short Stress Treatment of Observed and Simulated: (a) Alfalfa Yield from Each Harvest; (b) Average Soil EC

(Bali, personal communication, 1993), the dissolution and precipitation of gypsum was not considered. Simulations were performed for total alfalfa yield $(\mathrm{t} / \mathrm{ha})$, yield from each harvest (t/ha), average soil saturation extract $E C_{e}(\mathrm{dS} / \mathrm{m})$ and $E C_{e}$ $(\mathrm{dS} / \mathrm{m})$ in the soil profile to a depth of $1.2 \mathrm{~m}$.

Table 3 shows a comparison between observed and simulated total alfalfa yield for each irrigation treatment. The differences between observed and simulated total yield are less than $10 \%$. Leaf expansion, final leaf area index, and leaf duration are known to be reduced by water stresses (Acevedo et al. 1971; Eik and Hanway 1965). Hence, maximum leaf area index was reduced for stress conditions in model calculations.

Fig. 4(a) shows a good simulation of observed yield from each of the eight harvests for the optimum water treatment. Fig. 4(b) shows that the simulated average soil $E C_{e}$ to a depth of $1.2 \mathrm{~m}$ for the optimum check treatment deviated from observed values with increasing harvests, especially for the eighth harvest in which the yield was underestimated [Fig. $4(\mathrm{a})]$. Figs. 5(a, b, c) give the simulated $E C_{e}$ for soil depths for the optimum check treatment on June 4, September 4, and October 16,1991 . The simulated $E C_{e}$ in the surface soil depths are consistently higher than observed values.

Figs. 6( $a$ and b) show, respectively, a satisfactory comparison of observed and simulated yield from each of the eight harvests in the minimum stress treatment as well as the average soil $E C_{e}$. Figs. 7(a, b, c) respectively show the simulated soil profile $E C_{e}$ for the minimum stress treatment on June 4, September 4, and October 16, 1991.

Fig. 8(a) shows that observed alfalfa yield from each harvest for the short stress treatment was reasonably well predicted for the first four cuttings but not the last two. The short stress treatment was started on August 8, 1991 and there was no irrigation in August and September. So the model estimated the observed yield until the start of the stress rea- 

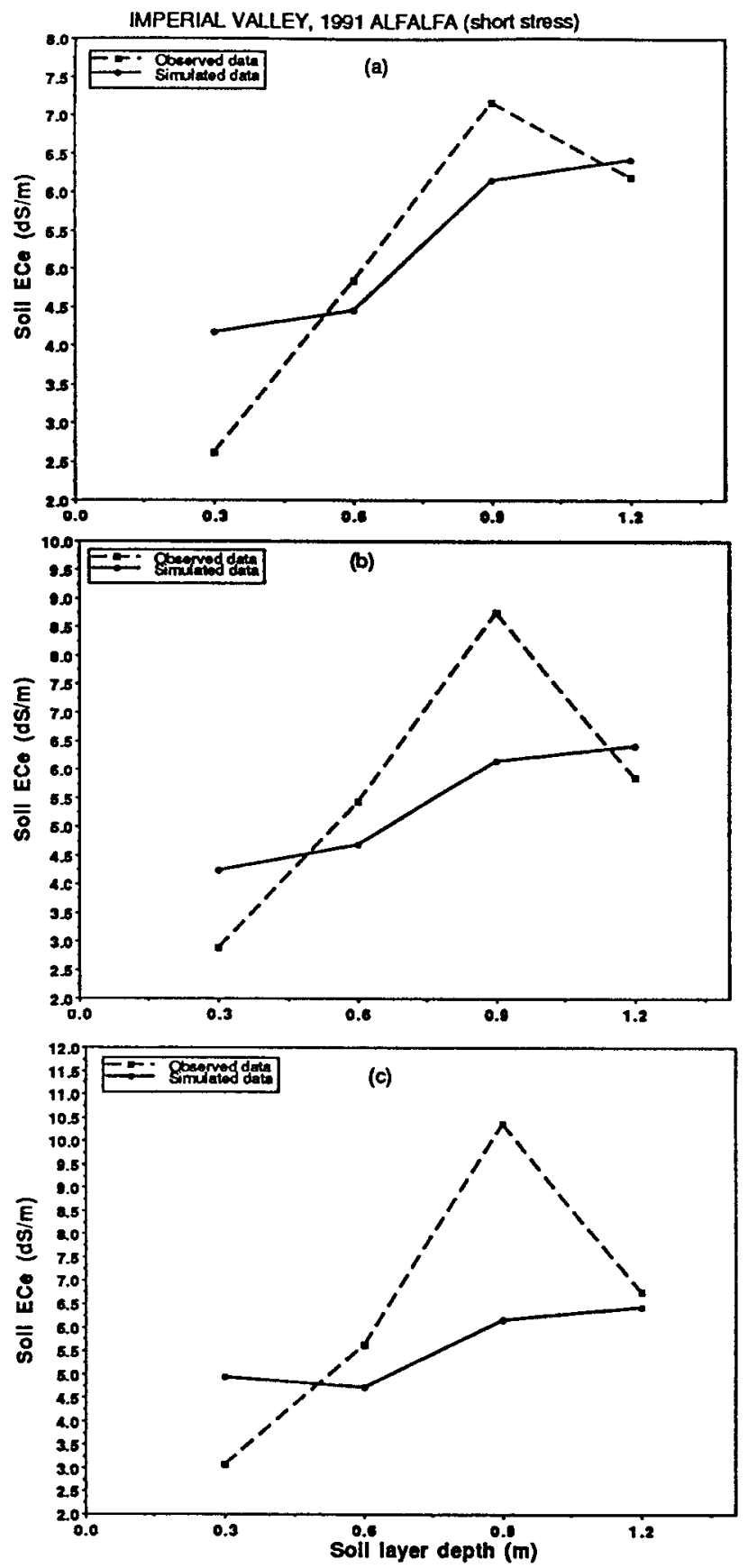

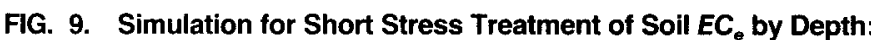
(a) on June 4; (b) on September 4; (c) on October 16

sonably well, but not for the period of high water stress. The discrepancy may be partly attributed to the model using optimal plant growth parameters, though the maximum leaf area index was reduced for the stress period. Fig. 8(b) shows the simulated results of average soil profile $E C_{e}$ for the short stress treatment in which the soil salinity was underestimated during the stress period, and hence, simulated yields are greater than observed [Fig. 8(a)]. Figs. 9(a, b, c) respectively show simulated soil $E C_{r}$ profile on June 4 , September 4, and October 16, 1991 for the short stress treatment. The simulated $E C_{\text {c }}$ profile on June 4 [Fig. 9(a)] was quite satisfactory because the stress was started after June 1991. In contrast, the simulated $E C_{c}$ profiles in the lower root zone became progressively poorer, especially in the $0.9 \mathrm{~m}$ depth, as the stress period was prolonged [Figs. $9(b$ and $c)$.

Fig. 10(a) shows the simulation of observed alfalfa yield from each of the five harvests for the long stress treatment. The long stress treatment was started on July 3, 1991 and a
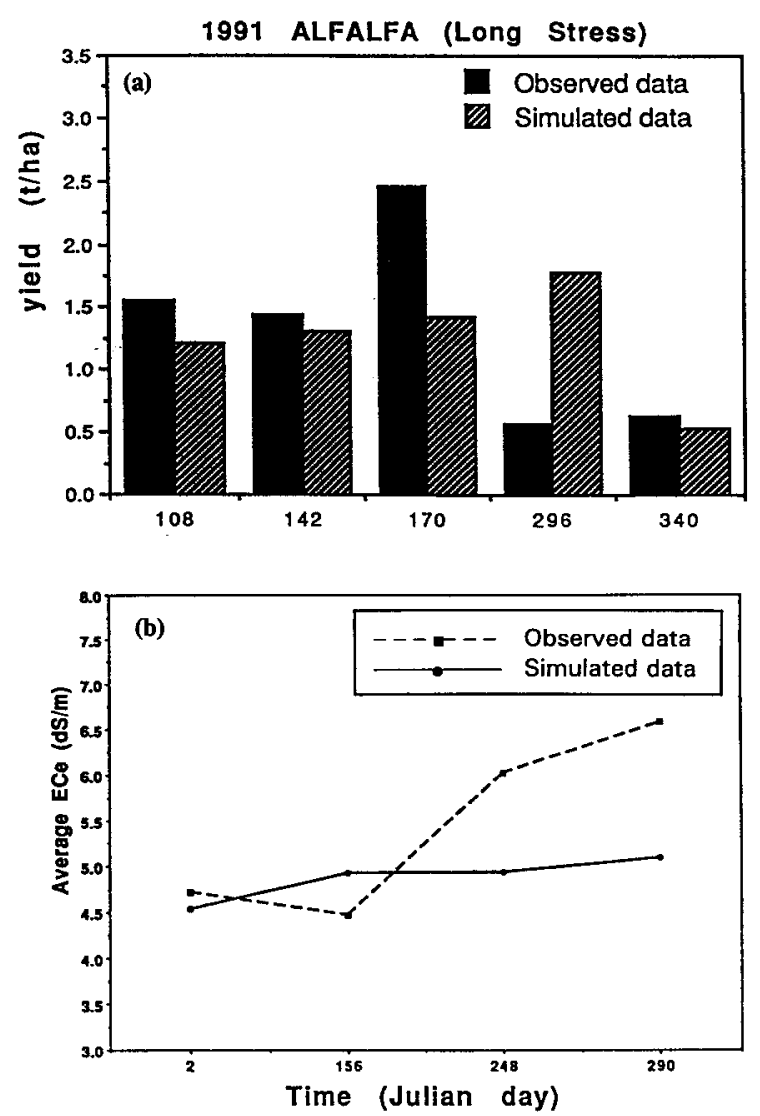

FIG. 10. Comparison for Long Stress Treatment of Observed and Simulated: (a) Alfalfa Yield from Each Harvest; (b) Average Soil EC $C_{e}$

total of seven irrigation events were not applied in July, August, and September as compared to the optimum check. The model, which was capable of estimating the alfalfa yield up to the beginning of deficit irrigation and at the end of the stress in October, was not quite capable of estimating the alfalfa yield at the third and fourth cuttings. Fig. 10(b) shows that observed average soil profile $E C_{c}$ for the long stress treatment was simulated during nonstress periods but not the stressed. Figs. 11(a, b, c) show the soil $E C_{e}$ at four soil depths on June 4, September 4, and October 16, 1991 for the long stress treatment. The simulation of the soil $E C_{e}$ profile on June 4 appears to be satisfactory [Fig. 11(a)] before the stress was initiated. But when the stress period is prolonged, the soil $E C_{e}$ profile [Fig. 11(b and c)] and yields [Fig. 10(a)] simulated by the model deviated significantly from measured values. The limitations of the model for conditions of prolonged water stress were previously mentioned.

\section{Sensitivity Analysis}

Sensitivity analyses were performed to evaluate the effects of variations in salinity of applied waters on total alfalfa yield under the four irrigation treatments described in the previous section. Table 4 shows the results of this analysis in which $850 \mathrm{mg} / \mathrm{L}$ total dissolved solids (TDS) was the salinity of applied water in the Robinson et al. (1992) field study. From Table 4 it can be seen that reducing the salinity of applied water in half to $425 \mathrm{ppm}$ TDS only slightly increased total yield of alfalfa for the four irrigation levels. It appears that water stress dominated over salinity stress. In contrast, doubling the salinity of the applied water to $1,700 \mathrm{ppm}$ TDS resulted in more pronounced yield reductions for all four treatments. Furthermore, with increasing salt concentration in the applied irrigation water, the decrease in the total alfalfa yield for the optimum check treatment is more than that for 

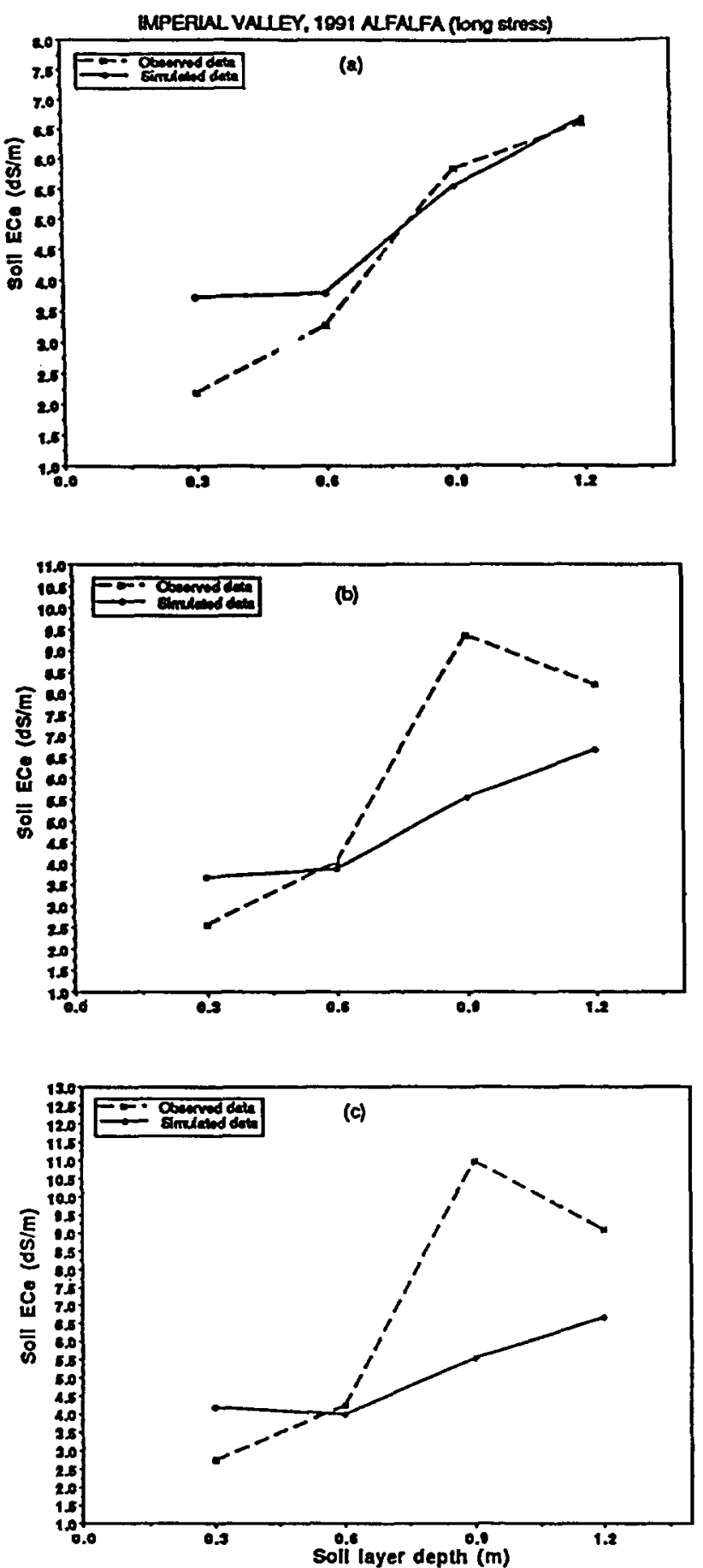

FIG. 11. Simulation for Long Stress Treatment of Soll EC, by Depth: (a) on June 4; (b) on September 4; (c) on October 16

TABLE 4. Comparison of Total Alfalfa Yields (under Different Salt Concentrations in irrigation Water)

\begin{tabular}{l|c|c|c}
\hline \hline & \multicolumn{3}{|c}{ Salt Concentration } \\
\cline { 2 - 4 } & $\begin{array}{c}C_{i r}=425 \mathrm{mg} / \mathrm{L} \\
\text { Treatment }\end{array}$ & $\begin{array}{c}C_{i r}=850 \mathrm{mg} / \mathrm{L} \\
(1)\end{array}$ & $\begin{array}{c}C_{i r}=1,700 \\
\mathrm{mg} / \mathrm{L} \\
(\mathrm{t} / \mathrm{ha})\end{array}$ \\
\hline Optimum check & $(2)$ & $(3)$ & $(4)$ \\
Minimum stress & 11.80 & 11.50 & 10.60 \\
Short stress & 10.80 & 10.50 & 10.70 \\
Long stress & 9.70 & 9.50 & 8.90 \\
\hline \hline
\end{tabular}

TABLE 5. Opportunity Cost of Water Foregone for Different Irrigation Treatments and Sallnity Concentrations

\begin{tabular}{|c|c|c|c|c|c|}
\hline \multirow[b]{2}{*}{$\begin{array}{c}\text { Treatment } \\
\text { (1) }\end{array}$} & \multirow[b]{2}{*}{$\begin{array}{c}\text { Water } \\
\text { foregone } \\
\text { (ha } \cdot \mathrm{mm}) \\
(2)\end{array}$} & \multicolumn{4}{|c|}{ Alfalfa Output Price } \\
\hline & & $\begin{array}{c}\$ 130 / \mathrm{t} \\
\text { (dollars/ } \\
\text { ha-m) } \\
(3)\end{array}$ & $\begin{array}{c}\$ 110 / t \\
\text { (dollars/ } \\
\text { ha-m) } \\
(4)\end{array}$ & $\begin{array}{c}\$ 90 / t \\
\text { (dollars/ } \\
\text { ha } \cdot \mathrm{m}) \\
(5)\end{array}$ & $\begin{array}{c}\$ 70 / \mathrm{t} \\
\text { (dollars/ } \\
\mathrm{ha} \cdot \mathrm{m}) \\
(6)\end{array}$ \\
\hline \multicolumn{6}{|c|}{ (a) $C_{i r}=425 \mathrm{mg} / \mathrm{L}$} \\
\hline Minimum stress & 49 & 2.37 & 1.96 & 1.55 & 1.14 \\
\hline Short stress & 256 & 0.95 & 0.79 & 0.62 & 0.46 \\
\hline Long stress & 430 & 1.42 & 1.18 & 0.93 & 0.68 \\
\hline \multicolumn{6}{|c|}{ (b) $C_{i r}=850 \mathrm{mg} / \mathrm{L}$} \\
\hline Minimum stress & 49 & 2.35 & 1.94 & 1.53 & 1.12 \\
\hline Short stress & 256 & 0.90 & 0.75 & 0.59 & 0.43 \\
\hline Long stress & 430 & 1.39 & 1.15 & 0.91 & 0.67 \\
\hline \multicolumn{6}{|c|}{ (c) $C_{i r}=1,700 \mathrm{mg} / \mathrm{L}$} \\
\hline Minimum stress & 49 & 2.12 & 1.76 & 1.39 & 1.02 \\
\hline Short stress & 256 & 0.76 & 0.38 & 0.30 & 0.37 \\
\hline Long stress & 430 & 1.26 & 1.04 & 0.83 & 0.61 \\
\hline
\end{tabular}

TABLE 6. Quasi-Rents and Respective Opportunity Costs for Different Irrigation Treatments and Sallnity Concentrations

\begin{tabular}{|c|c|c|c|c|}
\hline \multirow[b]{2}{*}{$\begin{array}{c}\text { Treatment } \\
\text { (1) }\end{array}$} & \multicolumn{4}{|c|}{ Alfalfa Output Price } \\
\hline & $\begin{array}{c}\$ 130 / \mathrm{t} \\
\text { (dollars/ } \\
\text { ha } \cdot \mathrm{m} \text { ) } \\
(2)\end{array}$ & $\begin{array}{c}\$ 110 / t \\
\text { (dollars/ } \\
\text { ha } \cdot \mathrm{m} \text { ) } \\
(3)\end{array}$ & $\begin{array}{c}\$ 90 / \mathrm{t} \\
\text { (dollars/ } \\
\text { ha } \cdot \mathrm{m} \text { ) } \\
(4)\end{array}$ & $\begin{array}{c}\$ 70 / \mathrm{t} \\
\text { (dollars/ } \\
\text { ha } \cdot \mathrm{m}) \\
(5)\end{array}$ \\
\hline \multicolumn{5}{|c|}{$(a) C_{i r}=425 \mathrm{mg} / \mathrm{L}$} \\
\hline $\begin{array}{l}\text { Optimum check } \\
\text { Minimum stress } \\
\text { Opportunity cost } \\
\text { Short stress } \\
\text { Opportunity cost } \\
\text { Long stress } \\
\text { Opportunity cost } \\
\end{array}$ & $\begin{array}{r}1,363 \\
1,247 \\
(116) \\
1,120 \\
(243) \\
751 \\
(612) \\
\end{array}$ & $\begin{array}{r}1,127 \\
1,031 \\
(96) \\
926 \\
(201) \\
621 \\
(506) \\
\end{array}$ & $\begin{array}{r}891 \\
815 \\
(76) \\
732 \\
(159) \\
491 \\
(400) \\
\end{array}$ & $\begin{array}{r}655 \\
599 \\
(56) \\
538 \\
(117) \\
361 \\
(294) \\
\end{array}$ \\
\hline \multicolumn{5}{|c|}{ (b) $C_{i r}=850 \mathrm{mg} / \mathrm{L}$} \\
\hline $\begin{array}{l}\text { Optimum check } \\
\text { Minimum stress } \\
\text { Opportunity cost } \\
\text { Short stress } \\
\text { Opportunity cost } \\
\text { Long stress } \\
\text { Opportunity cost }\end{array}$ & $\begin{array}{r}1,328 \\
1,213 \\
(115) \\
1,097 \\
(231) \\
728 \\
(600) \\
\end{array}$ & $\begin{array}{r}1,098 \\
1,003 \\
(95) \\
907 \\
(191) \\
602 \\
(496) \\
\end{array}$ & $\begin{array}{r}868 \\
793 \\
(75) \\
717 \\
(151) \\
476 \\
(392)\end{array}$ & $\begin{array}{r}638 \\
583 \\
(55) \\
527 \\
(111) \\
350 \\
(288)\end{array}$ \\
\hline \multicolumn{5}{|c|}{ (c) $C_{i r}=1,700 \mathrm{mg} / \mathrm{L}$} \\
\hline $\begin{array}{l}\text { Optimum check } \\
\text { Minimum stress } \\
\text { Opportunity cost } \\
\text { Short stress } \\
\text { Opportunity cost } \\
\text { Long stress } \\
\text { Opportunity cost }\end{array}$ & $\begin{array}{r}1,224 \\
1,120 \\
(104) \\
1,028 \\
(196) \\
681 \\
(543)\end{array}$ & $\begin{array}{r}1,012 \\
926 \\
(86) \\
850 \\
(162) \\
563 \\
(449)\end{array}$ & $\begin{array}{r}800 \\
732 \\
(68) \\
672 \\
(128) \\
445 \\
(355)\end{array}$ & $\begin{array}{r}588 \\
538 \\
(50) \\
494 \\
(94) \\
327 \\
(261)\end{array}$ \\
\hline
\end{tabular}

the long stress treatment because not much irrigation water is applied in the latter. Apparently, an increase in water salinity decreased soil water availability to the alfalfa or required more energy to satisfy its ET needs.

\section{ECONOMIC ANALYSIS}

This section evaluates the results given in Table 4 in an economic framework. Additionally, following the economic approach from Robinson et al. (1992), four alfalfa output prices will be used. These price levels range from $\$ 70 / t$ to $\$ 130 / \mathrm{t}$ at $\$ 20 / \mathrm{t}$ increments. The hypothesis is as follows: as alfalfa is water stressed and as the salt concentration in the irrigation water increases, production declines and farmers 
would receive less economic return. Urban water users might be willing to compensate farmers for the economic loss that would result from applying less irrigation water if that "saved" water were made available for urban use. The loss in return, or cost, can be used to determine the dollar amount farmers should be compensated (the loss in profits due to irrigation treatments other than the optimum) in undergoing deficit irrigation. Payment to farmers would come in the form of dollars from urban users for water given up in agricultural use.

The cost analysis of deficit irrigation is based on the loss in quasi-rents from not irrigating with the optimal quantity of water. Quasi-rent is the net return to farmers for harvesting alfalfa, which includes bale and stack costs but not the fixed costs in production.

Quasi-Rents $=$ Yield $\cdot($ Alfalfa Output Price - Harvest Cost $)$

The bale and stack costs comprising the harvest costs are $\$ 10.50 / \mathrm{t}$ and $\$ 4 / \mathrm{t}$, respectively (Robinson et al. 1992).

Table 5 displays the quasi-rents for each of the four irrigation treatments for the four different alfalfa prices. Each section of the table is based on one of the three different levels of salt concentration in irrigation water. The numbers in parentheses are the opportunity costs of undergoing a particular irrigation policy different from the optimum. These numbers represent the farmer's costs (lost revenue) in not implementing the optimal irrigation strategy. They are calculated by subtracting the quasi-rents for a particular deficit irrigation strategy from the quasi-rent for the optimal irrigation strategy. These opportunity costs represent the lowest price urban users would have to pay farmers for water not used in alfalfa production. As the stress irrigation strategy becomes more severe, it becomes more costly for farmers because of the reduced yield, and opportunity costs increase. Observing different output prices, the quasi-rents and opportunity costs increase with greater output prices. This is obvious since the value of the crop in relation to costs increase as prices that farmers receive increase. The salt concentration in applied irrigation water negatively affects these opportunity costs. This is because an increase in salt concentration reduces crop yield, but the reduction in yield is less as the stress irrigation strategy becomes more severe. This result is due to the fact that less water and consequently less salt is applied with greater deficit irrigation strategies.

The opportunity cost can also be presented in ha $\cdot \mathrm{mm}$ for water not used in alfalfa production. This information is shown in Table 6, with each section displaying a different level of salt concentration in the irrigation water. These numbers represent the per-unit value of water to urban users for a corresponding irrigation treatment strategy and alfalfa output price. It is relevant to note that the per-unit opportunity cost of water foregone in irrigation application increases as the output price of alfalfa increases, and decreases as the salt concentration increase. These results are due to the same reasons as discussed in the previous table. Table 6 also indicates that the short stress irrigation treatment strategy has the lowest per-unit opportunity costs of foregone water use. This is an interesting result, which means that with a given output price, urban water purchased from farmers costs less, per unit, for the short stress irrigation treatment strategy than any other treatment strategy.

\section{CONCLUDING REMARKS}

In this study one of the conceptual agronomic models, EPIC, was revised to model root zone salinity and biomass in alfalfa production on a field scale under optimal and stress conditions. The revised model was calibrated and validated with field data. The revised model was applied to simulate total alfalfa yield, alfalfa yield from each harvest, average soil saturation extract $E C_{e}$, and soil profile $E C_{e}$ under optimal and stress conditions.

The results indicate that the revised model can be employed to simulate total alfalfa yield and average soil $E C_{e}$ under optimal and stress conditions. Alfalfa yield from each harvest and soil $E C_{e}$ profile can be estimated for the optimum and minimum stress treatments quite satisfactorily. On the other hand, though the revised model can make reasonable estimations of alfalfa yield from each harvest and $E C_{e}$ of the soil profiles for the short and long stress treatments, its estimation becomes poor when the stress period becomes prolonged.

The results on model sensitivity suggest that an increase in salt concentration in applied irrigation water (beyond $850 \mathrm{mg}$ / L) would dramatically decrease the total alfalfa yield under all the four irrigaton treatments, especially under normal moisture conditions (optimum moisture check and minimum stress treatments).

The economic results display the value of water to farmers if they were to sell their water for urban use. These results indicate that the per-unit opportunity costs of water foregone from irrigation application are lowest for the short-term stress irrigation strategy. The results also indicate greater opportunity costs of foregone water as the output price of alfalfa increases and lower opportunity costs as salinity concentration in irrigation water increases. These aspects are both interesting and important in assessing the effectiveness of deficit irrigation best management practices.

Having considered the satisfactory simulation of several primary variables, as was the case in the present study, the revised model can be a very good practical tool for research and management purposes. Also, the revised model can be employed in assessing the economic effectiveness of best management practices.

\section{APPENDIX I. REFERENCES}

Acevedo, E., Hsiao, T. C., and Henderson, D. W. (1971). "Immediate and subsequent growth responses of maize leaves to changes in water status." Plant Physiol., 48,631-636.

Champion, D. F., Kruse, E. G., Olsen, S. R., and Kincaid, D. C. (1991). "Salt movement under level-basin irrigation." J. Irrig. and Drain. Engrg. ASCE, 117(5), 642-655.

Eik, K., and Hanway, J. J. (1965). "Some factor affecting development and longevity of leaves of corn." Agron. J., 57, 7-12.

Jackson, L. E., Stivers, L. J., Warden, B. T., and Tanji, K. K. (1994), "Crop nitrogen utilization and soil nitrate loss in a lettuce field." Fertilizer Res., 37, 93-105.

Karajeh, F. F., and Tanji, K. K. (1994). "Agroforestry drainage management model. III: filed salt flow." J. Irrig. and Drain. Engrg., ASCE, $120(2), 397-413$.

Karajeh, F. F. (1991). "A numerical model for management of subsurface drainage in agroforestry systems," PhD dissertation, University of California, Davis, Calif.

Kemper, W. D., Olsen, J., and De Mooy, C. J. (1975). "Dissolution rate of gypsum in flowing water." Soil Sci. Soc. Am. Proc., 39,458463.

Keren, R., and O'Connor, G. A. (1982). "Gypsum dissolution and sodic soil reclamation as affected by water flow velocity." Soil Sci. Soc. Am. J., $46,726-732$

Kincaid, D. C., Kruse, E. G., and Duke, H. R. (1979). "Paired hydraulic weighing lysimeters for evapotranspiration measurements." Winter Meeting of ASAE, ASAE, St. Joseph, Mich.

Kovda, V. A. (1983). "Loss of productive land due to salinization." Ambio, 12(2), 91-93.

Kruse, E. G., Champion, D. F., Cuevas, D. L., Yoder, R. E., and Young, D. (1993). "Crop water use from shallow, saline water tables." Trans., ASAE, 36(3), 697-707.

Robinson, E. F., Teuber, L. R., and Loomis, S. R. (1992). "Alfalfa water stress management during summer months in Imperial Valley for water conservation." Annu. Rep. to Metropolitan Water District of Southern California, Water Resources Center, University of California, and Imperial Valley Conservation Research Center Committee. 
University of California Desert Research and Extension Center, El Centro, Calif.

Robinson, F. E., Teuber, L. R., and Gibbs, L. K. (1994). "Alfalfa water stress management during summer in Imperial Valley for water conservation." Final Rep. to the Metropolitan Water District of Southern California, University of California Water Resources Center, and Imperial Valley Conservation Research Center Committee. University of California Desert Research and Extension Center, El Centro, Calif.

Sharply, A. N., and Williams, J. R. (1990). "EPIC-erosion/productivity impact calculator: 1. model documentation," Tech. Bull. No. 1768, U.S. Department of Agriculture, Washington, D.C.

Tanji, K. K. (1990). "Agricultural salinity assessment and management." Manuals and Reports on Engineering Practice, No. 71, ASCE, New York, N.Y.

Tanji, K. K., Helfand, G., and Larson, D. M. (1994). "BMP assessment model for agricultural NPS pollution."Final Rep. to State Water Resources Control Board: Hydrologic Science Paper 100027, Univ. of Calif., Davis, Calif.

Warden, B. T., House, B. W., Jackson, L. E., and Tanji, K. K. (1992). "Modeling of fate of nitrogen in the rootzone: management and research applications." Proc. California Plant and Soil Conf., California Chapter ASA, Fresno, Calif., 75-87.

\section{APPENDIX II. NOTATION}

The following symbols are used in this paper:

$C_{g}=$ solution concentration at any time;

$C_{g s}=$ solution concentration at gypsum saturation;

$C_{s}=$ average salt concentration;

$C_{s f}=$ final salt concentration;

$E C_{e}=$ soil saturation extract;
$E_{v}=$ amount of soil water evaporation;

$G_{d l}=$ mass of dissolved components of gypsum lost from soil layer $l$;

$G_{p}=$ mass of precipitated gypsum;

$G_{p l}=$ mass of evapoconcentrated components of gypsum moved to soil layer $l$;

$I=$ vertical percolation $(\mathrm{mm})$;

$K=$ dissolution coefficient;

$l=$ soil layer number;

$L=$ lateral subsurface flow $(\mathrm{mm})$;

$n=$ number of soil layers;

$P_{l}=$ wilting point water content;

$P_{o}=$ porosity;

$R=$ runoff $(\mathrm{mm})$

$S=$ salt mass associated with $W$;

$S_{l}=$ salt mass lost from soil layer $l$;

$S_{\text {ev }}=$ salt mass associated with soil water evaporation;

$S_{\mathrm{ev},}=$ salt mass moved to soil layer $l$

$S_{f}=$ final salt mass;

$S_{i}=$ initial salt mass;

$S_{i l}=$ initial salt mass in soil layer $l$;

$T=$ thickness of soil element;

$t_{c}=$ time when water leaves soil element;

$T_{s l}=$ total salt mass in soil layer $l$;

$v=$ Darcy velocity;

$V=$ actual flow velocity;

$W=$ total water flow (mm);

$\theta=$ moisture content; and

$\theta_{s}=$ saturated moisture content. 